\title{
慢性関節リウマチにおける肩鎖関節の X線学的検討
}

\author{
福岡大学筑紫病院整形外科 \\ 古 賀 崇 正・城 戸 正 喜 \\ 松 崎 昭夫
}

\section{Radiographic Findings of the Acromioclavicular joint in Rheumatoid Arthritis by \\ Takamasa Koga, Masayoshi Kido and Akio Matsuzaki \\ Department of Orthopaedic Surgery, Chikushi Hospital Fukuoka University}

\begin{abstract}
We shudied the radiographic findings in 15 cases of the classical rheumatoid arthritic shoulder (29 shoulders). These shoulders were classified into two groups according to symphomatology: 18 had symptomatic shoulders and 11 were non-symptomatic. Injection of local anesthetic was done into the acromioclavicular joint, the subacromial bursa, and the glenohumeral joint. Radiographs were graded according to the Larsen classification. Clinical symptoms and radiologic appearance are often poor indicators of the source of pain in the shoulder joint complex in patients with rheumatoid arthritis. About $30 \%$ of the shoulder were relieved of pain by acromioclavicular joint injection.
\end{abstract}

Key words : rheumatoid arthritis (慢性関節リウマチ), shoulder joint (肩関節), acromioclavicular joint arthritis（肩鎖関節炎）

はじめに

慢性関節リウマチ（以下 RA と略す）患者におけ る肩痛に対しては，主に肩甲上腕関節のX線変化と機 能障害, 疼痛との関連について述べられる事が多い。 今回, 肩痛を訴える RA 患者に対して, 肩鎖関節, 肩甲上腕関節のX線所見について検討した．また疼痛 発生源を明確にする目的で，局所麻酔剤を用い検索を 行った．その結果についても報告する.

\section{対象および方法}

肩痛を有する RA 患者のうち，肩関節周囲の外傷 歴, 手術歴を有さない症例を対象とした。症例は, clasical RA 患者, 15 例 29 肩, 男 5 例 (10 肩)，女 10 例 (19 肩) で, Steinbrocker の分類では, Stage 2: 11 例, Stage $3: 4$ 例, Class $2: 11$ 例, Class 3 :
4 例であった. 年齢は 42 才 74 才，平均年齢 61.3 才. 罹患年数は $2 \sim 40$ 年, 平均 12.5 年, 副腎皮質ホルモ ン服用歴を有するものは 6 例であった．手術歴のある 1 肩を除く 15 例 29 肩に対し肩銷関節，肩甲上腕関節 の左右の単純 X線前後像を用い, 肩痛を有する群と有 さない群について比較検討した。

X線分類には Larsen 分類を用い評価した。 疼痛発 生部位を明確にする目的で, 局所麻酔剂でのブロック を行った．まず肩鎖関節内に局所麻醉剤を $1 \sim 2 \mathrm{ml}$ 注入し，圧痛及び運動時痛に対し被検者自身に評価さ せ，疼痛が残存すれば次に肩峰下滑液包，肩甲上腕関 節に順次局所麻酔剂を注入し，その度評価を行った。 尚, 肩峰下滑液包への注入については，X線で肩峰と 上腕骨頭の狭小化がみられ腱板断裂が示唆されるもの については行っておらず, 腱板断裂の有無についての 評価む行っていない. 


\section{結果}

\section{$1 ： \mathrm{X}$ 線評価について}

肩甲上腕関節の $\mathrm{X}$ 線評価は，肩痛を有する 18 肩で は, Grade 0: 0肩, Grade 1: 6 肩, Grade 2:6 肩, Grade 3:2肩, Grade 4:4 肩, Grade 5: 0 肩で, 肩痛を有さない11 肩では, Grade 0：0肩, Grade 1:2 肩, Grade 2: 6 肩, Grade 3:2 肩, Grade 4:1肩, Grade 5:0肩であった.

肩銷関節のX線的变化は，肩痛を有する 18 肩では， Grade 0:0肩, Grade 1: 4 肩, Grade 2: 7 肩, Grade 3: 3 肩, Grade 4: 4 肩, Grade 5: 0 肩で, 肩痛を有さない11肩では, Grade 0：0肩, Grade 1: 1 肩, Grade 2: 7肩, Grade 3:2肩, Grade 4: 1肩, Grade 5：0肩であった. Grade 0及び Grade 5 のX線分類は認めなかった。

肩痛を有する 18 肩で，肩甲上腕関節の X 線所見の Grade 1 に対し肩鎖関節では, Grade 1：4 肩, Grade 2: 2 肩で, Grade 2 に対しては, Grade 2： 4 肩, Grade 3: 2 肩, Grade 3 に対しては, Grade 2: 1肩, Grade 3: 1 肩, Grade 4 に対しては, Grade 4：4肩であった。肩痛を有さない11肩では, 肩甲上腕関節の X線所見の Grade 1 に対し肩鎖関節 では, Grade 1:1肩, Grade 2:1肩で, Grade 2 に対しては, Grade 2：5肩, Grade 3:1肩, Grade 3 に対しては, Grade 2: 1 肩, Grade 3: 1 肩, Grade 4 に対しては, Grade 4: 1 肩であった （表-1 ）．肩痛を有する群と有さない群との間におい て肩鎖関節と肩甲上腕関節のX線変化においては，有 意な差を認めなかった。

2 : 局所麻酔剤でのブロックの効果について 肩痛を有した 18 肩対し局所麻酔剂でのブロックを

18肩

（4肩：消失、2肩：軽減、12肩：効果なし）

5肩

(2肩 : 軽減、3肩 : 効果なし)

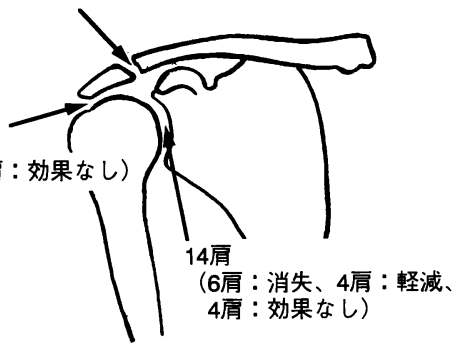

図- 1 局所麻酔剂の注入部位
表- 1

肩痛を有する 18 肩

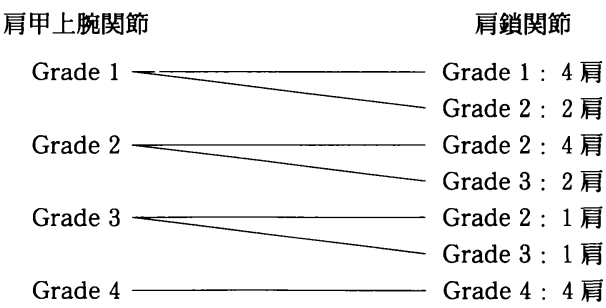

肩痛を有さない 11 肩

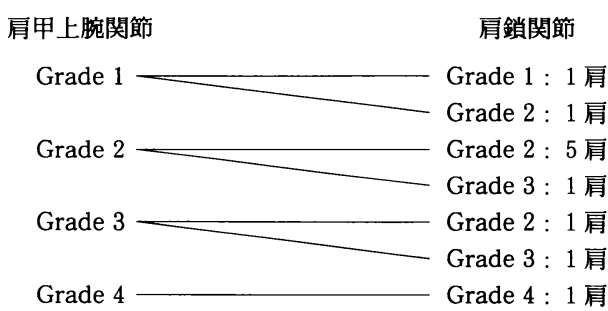

行った．肩鎖関節に注入した 18 肩では，4 肩で疼痛 が消失， 2 肩で軽減した，肩峰下滑液包に注入した 5 肩では，2 肩で軽減をみたが， 3 肩では効果がみられ ず症状が残存した，肩甲上腕関節に注入した 14 肩の うち，6肩で疼痛が消失，4肩で軽减，4肩が残存し た (図-1).

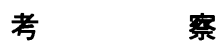

$\mathrm{RA}$ における肩甲上腕関節の X線上の変化，機能障 害及び疼痛について報告は多くみられるが，肩鎖関節 のX線変化について言及している報告は少ない(1)5)6)7)8). 日常診療で肩関節周囲の疼痛を訴えて来院する RA 患者は多く，その診察においてX線所見と疼痛発生源 が一致しないことをよく経験する ${ }^{3) 4)}$. 肩鎖関節，肩 甲上腕関節の X線所見においても, 肩痛を有する群と 有さない群との間に有意な差は認めなかった，肩甲上 腕関節のX線変化が進行していても約 $30 \%$ が肩鎖関 節のブロックで疼痛が消失または軽減しており，肩の 疼痛発生源として，肩鎖関節も考慮すべきである.

また今回の肩鎖関節と肩甲上腕関節の X 線所見を Larsen の分類 ${ }^{2)}$ を用い分類したが，肩鎖関節では早 期より鎖骨遠位端の先細り像，または関節裂隙の開大 するものが多くみられ（図-2），関節裂隙の狭小化 像を示すものは少なく $\mathrm{RA}$ 患者の肩鎖関節の X 線分 


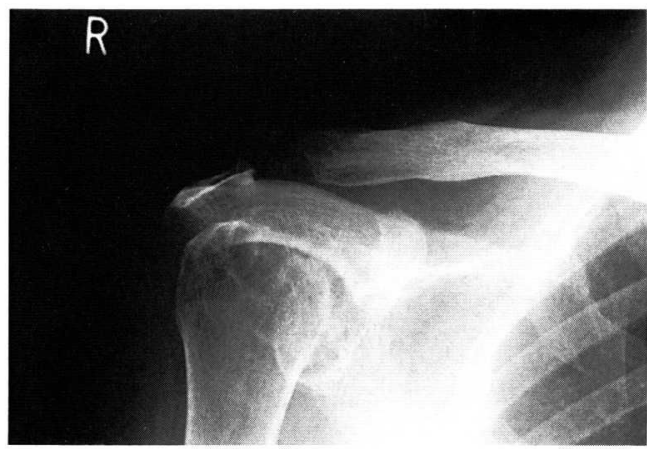

a : 肩鎖関節の関節裂隙の開大 piano key 様 sign を認める

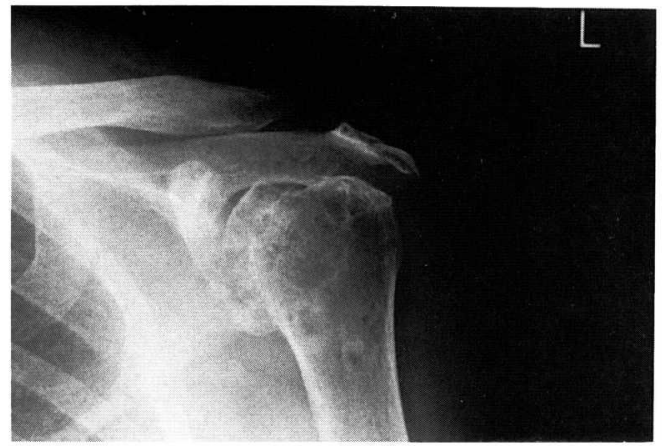

b：鎖骨遠位端の先細り

図- 2

類に用いることは不適当と思われた。

$$
\text { ま と め }
$$

1) 肩鎖関節，肩甲上腕関節の $X$ 線変化について検 討した.

2 ）慢性関節リウマチにおける肩鎖関節のX線評価 においては，早期より鎖骨遠位端の先細り，関節裂隙 の開大を生じるものが多く Larsen 分類は不適当と考 える.

3 ) 慢性関節リウマチの肩痛を訴える患者の約 30 \%は肩鎖関節への局所麻酔剤で疼痛が消失または軽減 しており, 慢性関節リウマチの肩痛の疼痛発生源とし て肩鎖関節についてあ考慮すべきである.

\section{参 考 文 献}

1) Kelly. I. G. : The source of shoulder pain in rheumatoid arthritis : Usefulness of local anesthetic injection.
J Shoulder Elbow Surg. 3 : 62-65, 1994.

2) Larsen A, Dale K, Eek M. : Radiographic evaluation of rheumatoid arthritis and rclated conditions by standard reference films. Acta Radiologica Diagnosis. 18 : 481-491, 1976.

3）松崎昭夫 : 肩鎖関節炎による肩甲帯の痛みについて. 肩関節, $9: 37-39,1985$.

4）松崎昭夫：筋腱症による肩痛について，肩関節, 12-2 : 246-249, 1989.

5）大薮直子ら：慢性関節リウマチにおける肩関節の変化 関節の外科, $16: 160,1989$.

6) Petersson J. : The acromioclavicular joint in rtheumatoid arthritis. Clin Orthop $223:$ 86-93, 1987.

7) Simpson. N.S, et al. : Extra-glenohumeral joint shoulder surgery in rheumatoid arthritis: The role of bursectomy, acromioplasty, and distal clavicle excision. J Shoulder Elbow Surg. 3 : 66-69, 1994.

8）吉松俊一, 長島健治, 小早川宏典 : 慢性関節リウマチ における肩鎖関節像について. 中部整災誌, 14:621622, 1971. 